\title{
The Development of Czech Environmental Policy 1990-1995
}

\author{
A Sociological Account \\ PETR JEHLIČKA* \\ Faculty of Science, Charles University, Prague
}

\begin{abstract}
Using the case study of the Czech Republic, the article examines the link between the development of environmental policy and the more general social and economic development of a post-communist society. The initially progressive arrangement of environmental agencies and procedures of the early 1990s, which were in tune with the concurrent development in the West, was abandoned due to the arrested expansion and diversification of the policy community. The ethos of environmental policy-making of the early 1990s, which was a consequence of the special circumstances of that period, could not be maintained in the following years as there was no sufficiently strong social group underpinning and advocating these changes. This is documented on the inability of journalists to grasp and further communicate complex environmental issues, and on the non-existence of a social stratum corresponding to the 'new middle class', from which Western environmental groups draw their support.
\end{abstract}

Czech Sociological Review, 1999, Vol. 7 (No. 1: 37-50)

\section{Environmental policy during the first half of the $1990 \mathrm{~s}$}

When the first (and the last) federal government body in the area of the environment was created in 1990 in what was then Czechoslovakia, it had a surprisingly progressive structure. It was not an ordinary ministry dealing with 'a sector', but a committee headed by a chairman (instead of a minister). This institutional arrangement reflected an idea that the environment should not be treated as a particular and separate sector of government policy, but rather that environmental considerations should penetrate all government policies. Its members were the ministers of the environment of both republics, deputy ministers of foreign affairs, finance and economy and also chairmen of committees of the environment of all three parliaments. This new federal authority focused mainly on legislative, strategic and international aspects of environmental policy.

At the republic level, attempts were also made to overcome the legacy of the past and move environmental policy-making to a more advanced stage, certainly at least by means of what broadly resembled structural reorganisation [Weale 1992]. For instance, a comprehensive Czech environmental inspectorate was created, taking over inspections of water management and air pollution and thus covering waste management, forest protection and water management, and air pollution. The establishment of the Czech Ministry of the Environment in January 1990 signalled the end of the highly ineffective and sectorally divided old environmental protection arrangements. One of the major acts of the Ministry was the preparation of the 'State Programme for the Protection of the Environment'. The programme set guidelines for relevant state institutions, a strategy for legisla-

\footnotetext{
*) Direct all correspondence to Petr Jehlička, Department of Social Geography and Regional Development, Faculty of Science, Charles University, Albertov 6, 12843 Praha 2, phone +420 2 2195 2246, fax+4202296 025, e-mail pjehlick@mail.natur.cuni.cz
} 
tive work and environmental policy development, and proposals for handling environmental research, education, regional environmental problems and international cooperation.

Apart from short-term oriented 'first aid' programmes aimed at fast reduction of mainly air and water pollution in the form of 'end-of-pipe' solutions and clean-up projects, the ministries of the environment were also concerned with long-term considerations as documented by the emphasis placed on environmental education and research. While at a practical level the effort to embark on a more progressive approach to environmental policy foundered, at least at the level of official rhetoric, there were attempts to shift the focus from reduction of the amount of pollution towards the adoption of the principle of prevention. For instance, this principle was temporarily applied when competencies over land use planning and building code were transferred from the economic ministries to the Ministry of the Environment. It did not take long, however, before these powers were removed from the Ministry of the Environment and returned to their original holders.

This short period of about two years at the beginning of the 1990s when the relationship between the environment and economy was not simply regarded as a zero-sum game, when attempts were made for integrated pollution control and when more advanced principles such as the principle of prevention were employed, was followed, starting June 1992 when the second general elections were held, by a new period during which many progressive features were abandoned. What was previously seen as a necessary first step to fundamental improvement of the state of the environment - clean-up and installation of end-of-pipe technologies - suddenly became the ultimate goal of pollution control policy. The Ministry of the Environment lost some of its newly gained competencies and the environment again became a discrete policy area. Selected problems once again came to represent environmental issues at the expense of others and were presented by the state authorities as indicators of an officially proclaimed overall improvement of the state of the environment. In the Czech context, an example of the former is air pollution, partly in response to the adverse effects of air pollution, in particular its links to the poor state of health of the population living in the most polluted areas.

To document an almost anecdotal dimension of the U-turn of Czech environmental policy in the course of the first half of the 1990s it suffices to say that the notion of sustainable development was for a certain period completely banned from official government documents despite frequent references to the notion in Czech environmental legislation passed just a few years earlier.

A remarkable feature of the first 'enthusiastic' period after 1989 (November 1989mid-1991; see Jehlička and Kára [1994] for more details) was the close relationship between state officials and activists from non-governmental environmental groups. The high degree of influence of environmental group activists on government's environmental policies, certainly unusual by international standards, was embodied in 1990 in the founding of the Green Parliament that was initiated by the Czech Ministry of the Environment as its consultative body. The Green Parliament's members were representatives of the majority of the existing environmental groups at that time.

This effort to open political processes and enable public participation in the formulation of environmental policies sharply contrasts with the subsequent situation marked 
by a culture of secrecy and the effort to exclude citizens from environmental decisionmaking, which increasingly resembled practices of the communist regime.

It was often the case that people who criticised the communist government for being responsible for environmental crisis in Czechoslovakia were also among the chief proponents of democracy. They were publicly denounced by the communist authorities and their views were portrayed by the controlled media as a threat to the progress of the communist society.

By the mid-1990s, after six years of democratic government, the situation was, worryingly similar. As at the end of the 1980s, Czech environmentalists appeared in the middle of the 1990s on a list of subversive elements which was drawn up by the state intelligence services. In addition to the accusation of being a threat to the well-being of society, this time they were also deemed to pose a threat to democracy. Thus, while maintaining their views and goals, environmentalists in the eyes of the government and a certain section of the media went through a paradoxical transformation from being one of the major proponents of democracy to one of its major threats [Fagin and Jehlička 1997].

At an international level, the actions in the early 1990s of the Federal Committee chaired by Josef Vavroušek also differed markedly from the otherwise more common low-key mode of Czech foreign policy. The publication 'Europe's Environment. The Dobříš Assessment' [Stanners and Bourdeau 1995] initiated by him and particularly the first pan-European conference of ministers of the environment held in Dobříš castle near Prague in 1991 were the most tangible results of his effort to achieve environmental improvement in the Czech Republic within the European framework. The goals of the conference were:

“(...) to upgrade substantially the existing European environmental protection and restoration institutions, national as well as international, and to integrate them into a pan-European system of co-ordinated 'mechanisms' of environmental efforts at the continental level. (...) The second Dobříš objective was to develop, implement and then periodically to revise an environmental programme for Europe. (...) But the third objective was the least conventional and, in my view, the most important. I wanted the ministers to start to discuss human values and environmental ethics for sustainable development as the basis for such ways of life which can re-establish harmony between humankind and Nature." [Vavroušek 1993]

Hence it can be argued that at the beginning of the 1990s Czechoslovakia took an active part in the effort to shape environmental policies in Europe. Immediately after the fall of the old regime, one of the most important goals of Czechoslovakia and later the Czech Republic was membership of the EU. The Association Agreement was signed in 1991, which started the process of harmonisation of Czech laws and standards, including environmental legislation. In contrast to the early 1990s, in the subsequent years the Czech Republic no longer sought to be active in the arena of international environmental policy. Half a decade of harmonisation of the country's environmental standards with the EU delivered an unexpected outcome. The Czech Republic's environmental co-operation with the EU institutions as well as some consequences of domestic environmental policies came under criticism from the EU Commissioner for the Environment. The Czech Republic was warned that the environment could become a narrow point of integration to the EU. For instance, Czech authorities were criticised for their unwillingness to release information necessary for EU transboundary environmental projects [Čech 1997] and for a lack of attention to energy efficiency [Poláček 1996]. 
This stemmed from the fact that environmental harmonisation of the Czech legislation remained for the most part only at the level of 'formal implementation' (i.e. the incorporation of EU legislation into national law) as opposed to 'practical implementation' (i.e. the application of this national programme to effect the required changes in the behaviour of target groups). As was often the case with other policy areas, Czech environmental policy, both domestic and international, was to a great extent merely a limited formal imitation of Western (in this case EU) environmental policy. Formally identical or similar institutions and processes were not functional or acquired their own logic of operation, which was often sharply different from their Western models.

While at least some government departments and agencies and policies rhetorically and formally embraced the EU policy line broadly defined as ecological modernisation, especially at international fora, domestically both the interpretative and action frames [Jachtenfuchs and Huber 1993] significantly differed from the meaning of this concept. The actual content of practical environmental measures remained firmly in the spirit of the reactive strategies of the 1970s. In the middle of the 1990s environmental problems were still basically seen as problems of pollution, which were to be resolved by scientific expertise, progress of technology and the installation of end-of-pipe devices.

\section{Alternative accounts}

A standard explanation of the above-described developments employs concurrent broad domestic social and economic processes. On the one hand, it is argued that environmental issues slipped down the agenda due to a certain improvement of the state of the environment as a consequence of the slowdown of the economy. On the other hand, resultant serious economic problems are alleged to have led to social problems which replaced the environment as a major issue.

On the basis of the findings of my research (over 30 interviews with politicians at central and local level, NGO activists, academics, civil servants and teachers; two questionnaires, each yielding more than 300 responses; a content analysis of a leading Czech daily; analysis of academic publications) I propose an alternative explanation. While certain peculiarities of the domestic political setting such as the highly centralised character of the Czech state or the intentional effort of state authorities to undermine the development of civil society contributed to fast abandonment of newly established institutions and practices once their proponents lost their position, I would argue that the underlying causes have deeper roots.

As an observer of Czech environmental politics and policy in the early 1990s I was struck by the fact that the above-described progressive approach to environmental policy of the official state environmental agencies had no social underpinning. Superficially it seemed that there was, at least immediately after the demise of the old regime, strong environmental concern among the general public. It is now established in most academic accounts of the pre-1989 high environmental awareness of the Czech general public that the environment figured in the ecological discourse primarily as a tangible symbol of the wider ills of the socialist system [Holy, 1996]. However, even that genuine environmental concern as evidenced by results of various opinion polls did not go beyond people's worries about effects of pollution on their health and/or about environmental degradation of a 'local' character directly experienced by them. Furthermore, according to all opinion polls conducted since 1991, people have become ever more satisfied with the state of the environment. 
These findings led me to focus on underlying factors of the "new politics of pollution' [Weale 1992] of the 1980s in the West and draw comparisons with the Czech case. It was apparent that despite the effort of the first post-communist generation of environmental policy-makers to get wider segments of society involved, environmental regulation remained a matter for specialists and those few former environmental activists turned politicians who seized the opportunity offered by special circumstances of the immediate post-communist period.

A discrepancy between the intentions and deeds of the first post-November 1989 group of environmental policy-makers in terms of fundamental environmental reform and a superficial character of environmental reporting in Czech mass media that did not correspond with what was actually going on at higher political levels raised a question of to what extent the process of the emergence of the 'new politics of pollution' as it occurred in the West in the 1980s could be applied to post-communist societies. My hypothesis was that the process of policy community expansion associated with general social trends, which was the crucial factor behind the transformation of pollution control policy in Western Europe by the early 1990s, reached only an early stage in the Czech Republic.

\section{The underlying factors of the transformation of pollution control policies}

Weale argues that the transformation of pollution control policy was related to the expansion of environmental groups whose capability to change the character and functioning of the policy community depended on a number of more general social and economic changes:

"Environmental groups have benefited from rising educational standards, both in terms of support, since the better educated frequently value environmental amenity highly, and in terms of providing activists and a constituency that are scientifically and socially literate. The ability to challenge the policy decisions of existing elites in part depended upon showing technical competence, and rising educational standards have supplied new generations of supporters able to handle complex bodies of information. A related trend has been the development of specialist journalists in science and environmental affairs who have been able to explain technical issues in an accessible way." [Weale 1992]

Drawing on this line of argument in my own research I set out to examine to what extent these conditions for the development of new politics of pollution were in place in the Czech Republic in the late 1980s and early 1990s. I pursued the following three interrelated directions of research:

1. Examination of environmental discourse in the media at the beginning of the 1990s;

2. Analysis of the potential of the academic sphere for stimulating the process of learning;

3. Opportunities/constraints for learning stemming from the (under)development of civil society.

\section{Environmental discourse in the media}

The empirical basis of the content analysis was the entire environmental coverage in the Czech quality daily with the largest circulation - Mladá fronta - between 1 November 1988 and 31 October 1992. The communist period was included in the analysis as one of my major aims was to observe how impacts of transition from one political system to another on a broad area of environmental issues was reflected in environmental coverage in the most popular Czech daily. I wished to see how this diverged from the standard of 
the communist period and to what extent the environmental coverage no longer subjected to censorship converged with western development in this field.

The result of my analysis was a list of environmental articles produced for each month containing the date, the headline of an article, its main subject or issue focus expressed in several key words, journalist genre, the length of an article measured in columns, an author, the originator (if distinguishable) of an article and its geographical location in the case of the news's foreign reference.

Articles were classified according to five different genres: news; note; comment; interview and analysis; and according to 34 issue areas. While it needs to be recognised that the various issue areas could not often be entirely separated, they were an indicator of the primacy focus or emphasis of coverage.

The extensive environmental coverage in Mladá fronta in the last period of communist rule in Czechoslovakia, documented in my research on the last 12 months of the old regime, and the subsequent wave of environmental reporting revealing the legacy of communism, did not produce any long-lasting concern for the environment. However, it directed attention to certain issues, such as air pollution, and presumably prompted politicians to act - to adopt new laws addressing the problem. But the proposed solution (installations of end-of-pipe technology) was fully in line with measures used in dealing with any other problems. Articles whose arguments would challenge traditional and wellestablished modes of behaviour and social norms, scarcely appeared in the newspaper.

The outburst of environmental coverage in the last phase of the old rule could therefore be best interpreted as an indirect criticism of the communist regime itself. The claim that the extensive environmental coverage was partly meant to draw attention to deficiencies of the political system rather than an expression of the genuine environmental concern of the journalists and the society as a whole, is supported by two facts. First, after the demise of the communist regime, environmental coverage shrank relatively quickly. Society at large, as well as the media, were losing interest in the environment, while at the same time these issues were far from being resolved. Second, many new environmental problems brought about by the new conditions of post-communist economic and social life passed unreported in the media including Mladá fronta.

Analysing an uneven distribution of variable problems in the mass media over time makes sense because, as Hansen [1993] pointed out, it is to do with the way in which elaboration and maintenance of the problems in public arenas offer insights into the power of different groupings in society to define what should be the focus of public concern, action, and ultimately, resource allocation. And this is precisely what the content analysis of Mladá fronta's environmental coverage enabled me to understand.

The analysis of the Czech daily provided an insight into how environmental problems were actually presented by those who had access to news creation. One of the findings of my analysis of environmental coverage in Mladá fronta was a conspicuous lack of news either created or originating outside the fora of conventional and official politics and science. The views of 'counterexperts' and activists of environmental groups, who in Western environmental coverage often function as agents of alternative views, was for most of the time of the analysis almost entirely lacking in the coverage. Environmental groups were active in Czechoslovakia, but they were rather small and therefore one likely reason for the absence of their voice in the newspaper was a lack of political power to get access to the media and to make their voice heard. 
One of the most peculiar features of Mladá fronta's environmental coverage was the dominance of domestic issues throughout the whole period under scrutiny. The annual share of domestic environmental coverage in total environmental coverage never dropped below 72 per cent and was most of the time over 80 per cent. In contrast, the combined categories of international and global environmental coverage only once exceeded 20 per cent and for most of the period made up only over 10 per cent. Lacey and Longman [1993] conducted a content analysis of the British press whose period under scrutiny considerably coincided with my analysis of Mladá fronta. For instance, during these 30 months The Guardian published 504 articles containing reference to the 'greenhouse effect' and 436 articles mentioning the expression 'global warming' ${ }^{1}$ The same figures related to The Times's coverage of these two phrases were 431 and 392. On the other hand, Mladá fronta published in the same period 16 articles, whose main thrust was global warming.

A pro-active approach to the international environmental co-operation of the postcommunist administration passed unnoticed by the media and Mladá fronta was no exception in this respect. To a certain extent, such an approach by the media was maintained as regards the first pan-European conference of ministers of the environment convened and organised by the Czechoslovak government in June 1991. If an attempt at being in the forefront of the European environmental diplomacy hardly achieved recognition in Mladá fronta, it was not utterly unexpected that the UN Conference on Environment and Development in 1992 received very poor coverage too.

\section{Academic sphere}

In Czechoslovakia during a short period after 1989 plans for establishing university faculties designed to carry out teaching and research on the environment were drawn up. Symptomatically, the intention was to locate them in the areas of the severest pollution (northern Bohemia and northern Moravia) and they were meant to concentrate on environmental science and technology. These plans were abandoned before they could be implemented, mainly due to lack of financial means and waning support for the environmental cause. In general, very little was done elsewhere by the state bodies to promote research and teaching in this field. Few departments of environmental studies and research programmes on environmental issues were established. Courses of various kinds on environmental issues were taught usually within faculties and departments of natural sciences, and students kept studying the management of protected areas and scientific analytical methods in the same manner as they did prior to 1989. For instance, Charles University Centre for the Environment compiled a list of all courses related to the environment taught at this the most prestigious Czech university in the academic year 1993/1994. Out of the total of 211 environmental courses available, only 20 had the character of a social science course.

Social science in general continued to be a marginalized area of academia. There were still very few opportunities to study social sciences. The number of candidates who in the first half of the 1990s wanted to study social science at the Prague faculty was regularly ten times higher than the number of accepted students. This corresponded with

1) Due to Lacey and Longman's methodology a great deal of these articles contained both phrases and therefore it is impossible to find out how many articles dealing with the effects of greenhouse gases on atmosphere there actually were; the minimum was 436 . 
very few teaching opportunities in social science and in environmental studies in particular.

This was a situation which hardly favoured the development of environmental learning. There were no or very few foci in terms of departments, conferences, seminars and journals where ideas could be generated in academic discourses. Few academic books by domestic authors were published, especially in social sciences. As a consequence of the past there were only few potential authors in the first place. Secondly, because of the disappearance of subsidies it became financially increasingly difficult to publish any academic book, let alone in a 'small' discipline. The restricted access to foreign academic journals and books due to lack of financial means still persisted too.

Practical difficulties hindering environmental learning in the existing niches included a lack of funding for this type of academic work and for subscription to foreign journals, lack of contacts with foreign academics working in the same field, few domestic books published and a lack of domestic academic journals. What proved to be an especially harmful feature of the organisation of academia in the Czech Republic, was the tradition of carrying out work within clearly defined discipline boundaries, and the reluctance of academic authorities to accept and support interdisciplinary research.

As a consequence of the above-mentioned reasons, environmental learning in the Czech Republic in the post-communist period did not advance significantly compared with the situation prior to 1989. After a short enthusiastic spell in 1990-1991, things in many ways returned back to normal. The lack of academic research base of environmental studies from the past turned out to be crucial. No systematic measures aimed at ameliorating this situation were taken after 1989. Therefore, environmental thought in the Czech Republic in the first half of the 1990s did not, in a general sense, catch up with the contemporary development in the West. This view is confirmed by findings of a report of the Regional Environmental Center for Central and Eastern Europe [Environmental... 1994] which was drafted on the basis of information provided by leading environmental academics, activists and government officials:

"It is interesting to observe that a comprehensive opinion about the environmental problems of these (Eastern European) countries or the need for a total change in approach is nearly entirely missing from most of the individual reports (i.e. on individual countries). The lack of the aspiration for a reorganised, and broadly based approach connecting economy and environment is an important general warning towards the nature of environmental problems in the region."

\section{Membership of the Green Party and of environmental groups}

Initially it was the Green Party, rather than the environmental groups, which seemed to be the champion of the environmental cause in former Czechoslovakia. Founded as the first political party after the demise of the old regime it attracted wide support and ranked high in pre-electoral opinion polls in 1990. However, despite this enthusiastic origin and strong support, its fortunes did not last long. It was losing members and electoral support. Financial decline was a logical consequence. The lowest point in the short history of the Green Party came with the 1996 general elections in the Czech Republic, when the party did not secure enough financial means to field its candidates.

My Czech Green Party questionnaire was carried out at the point prior to which the party lost a large share of its initial membership at the end of 1992 and at the beginning of 
1993. The return rate of my questionnaire, which was sent to all members of the party in Bohemia, was more than 40 per cent (311 returned out of over 700 sent out).

I also sought to find Czech environmentalists beyond the Green Party's ranks in order to obtain comparative data which would enable me to draw more reliable conclusions about the nature and character of Czech environmentalism. I realised during my initial interviews with the Czech Green Party's leading figures that the party members were likely to be a rather different group to Western Greens and environmentalists in general. Therefore, I turned my attention to members and activists of environmental groups. A convenient way to reach members of different environmental groups was to publish a questionnaire in a magazine which these people read. I chose the only wellknown and prestigious magazine for environmental activists which was published in the country at that time - Nika.

Nika's circulation dropped sharply from about 10,000 in 1989 to 3,500 in November 1992 when my eight-page questionnaire was published in it. Nonetheless, even after this significant fall, Nika was still by far the most well-known and most respected environmental magazine in the Czech Republic. The number of returned questionnaires was 310 .

The major legal environmental organisations existing during the communist period were very small by contemporary Western standards. Even more surprisingly, in terms of the size of their membership, environmental organisations legally existing under communism started to decline immediately after November 1989. This observation can be well illustrated by the example of the Czech Union of Nature Conservationists (CUNC), an association of primarily conservationist character. It had 25,000 members at the end of 1989, 8,000 members in 1993 and about 6,000 two years later. This trend was confirmed by the Nika questionnaire.

Another finding is that the decline of the 'old' organisations in the post-1989 period was not accompanied by the formation of 'new' organisations which would match the old ones in their size. Admittedly, in the wake of political upheaval there was an upsurge of a large number of various organisations, but most of them were tiny and often soon disappeared without a trace. By the mid-1990s there were only three major environmental organisations of this kind in the Czech Republic. The Rainbow Movement had at the end of 1995 approximately 300 members, Children of the Earth registered about 600 members, and the number of Greenpeace supporters did not exceed several hundred [Fagin 1996].

It can be concluded that six years after the 1989 political change, the combined membership of environmental organisations in the Czech Republic did not exceed the figure from 1989 and their influence was far smaller than during the turning period of the early 1990s. The fact that the political constraints on participation in and activities of environmental groups were lifted with the arrival of democracy, suggests that there were some other reasons for the arrested development of environmental groups and the decline of the Green Party. The small and effectively declining membership of environmental groups indicates that the pool of supporters of these groups was for some reasons limited.

There are strong indications that the Czech Greens saw the party primarily as a vehicle for alleviation of locally confined environmental problems which they personally experienced in their everyday lives and which they deemed to affect human health. In this sense, their environmental concern had a strongly anthropocentric character. Although 
they ascribed the same weight to global, national and local environmental problems influencing their decision to join the party, when they had to make a choice, they clearly gave the priority to typical tangible and in essence local environmental problems.

In this respect, the Greens were similar to the general public who, according to the results of various opinion polls conducted in the early 1990s, perceived air and water pollution as the most pressing environmental problems. There is also another indication that the foundation of the Green Party was a result of the popular environmental concern of the late 1980s. Forty-four per cent of those who were members of the party at the time of my survey joined the party during the first month of its existence. Furthermore, many answers suggest that the Czech Greens concentrated primarily on the environment and paid much less attention to other issues (social, economic and political) which a political party has to deal with as well. With a certain degree of simplification, it can be argued that by most of its members, the Green Party was perceived as a kind of environmental group campaigning on local environmental issues rather than a proper political party addressing the whole range of issues from a particular point of view.

Overall, the Czech Greens did not fit the Western stereotype of green party members - university-educated, post-materialist middle-class professionals who perceive environmental problems in their social, economic and global contexts and complexities.

Although the Czech Greens were a distinct group within the Czech society, the degree of their distinctiveness was much lower than that of the Nika readers. This group was more similar to Western environmentalists than the Czech Greens. Not only were a majority of them professionals with university degrees, but also many of them worked in the public sector - almost half of the Nika readers worked either in a local authority or academia. They were mostly non-religious. Forty-four per cent of them appeared to be postmaterialists which was double the share of the Greens and a percentage five times higher than among the Czech general public. Unlike the Greens, they gave a clear priority to the global over the local environmental issues. There is an indication that the environmental concern of the members of environmental groups among the Nika readers was of a less anthropocentric character than that of the Czech Greens. While for more than half of the latter group the fact that their activity can result in the improvement of human health was a decisive motivation for joining the Green Party, the Nika readers put considerably less emphasis on the detrimental effects of environmental degradation on human health. This was a decisive reason for joining an environmental group for only a quarter of those who did so.

While on the surface the Nika readers seemed to match Western environmentalists quite well, on closer inspection finer but very important differences emerged. First, although equally highly educated, the Nika readers experienced a very different type of higher education. Over 50 per cent of those who studied at an institution of higher education did science and medicine (out which more than half were biologists) and a quarter had their degrees from polytechnics. The second sharp difference was their right-wing political orientation as more than half of them regarded themselves to be right of the centre and also voted for right-wing parties. The third important difference was that only just over 40 per cent were post-materialists.

To conclude, neither group of the Czech respondents could be described as closely resembling Western environmentalists. The following section will put forward arguments 
explaining why there are only very few Western-like environmentalists in the Czech Republic.

It can be concluded therefore that in the Czech Republic in the first half of the 1990s the number of people who would resemble Western environmentalists was extremely small. In terms of the social and attitudinal profile the Czech Greens were effectively a different party to most Western green parties. Their purely anthropocentric concern with environmental pollution affecting human health was in tune with the general public environmental perceptions. In this respect, the Green Party was a direct consequence of Eastern European environmentalism of the late 1980s, whose characteristics was a rather limited scope of perception of environmental problems which neglected social and ethical dimensions as well as global economic and ecological interdependencies.

The fact that the Nika respondents were in some ways similar to Western environmentalists, does not substantially alter this conclusion. It has to be realised that this relatively large sample represented a very small total membership of environmental groups. The environmental movement in the Czech Republic and in the whole of Eastern Europe remained weak in the middle of the 1990s.

\section{Explanations}

While the structure of the economy in Central European communist countries was until the end of the old regime dominated by industry and most people were working in this sector, there was, nevertheless, a relatively strong tertiary sector. ${ }^{2}$ At the same time, the share of university and polytechnic graduates in the Central European population was lower than in Western Europe. Almost all jobs were entirely secure under communism. Hence, the first condition for emergence of the new politics of pollution - the spread of educated new middle classes with secure jobs - was in Central European communist countries fulfilled only to a limited extent.

Furthermore, after 1989, all post-communist countries experienced declining industrial output and the public and private service sector was the second fastest growing sector of the economy. Despite the expansion of this type of employment over the first half of the 1990s, ${ }^{3}$ no parallel growth in support for environmental groups and the Green Party occurred. In fact, quite the opposite took place while this sector significantly expanded. This confirms Poguntke's [1993] and Rootes's [1994] objections to structural change as a sufficient explanatory factor for support for environmentalism.

The second factor (according to Poguntke [1993]) - historical situation (ecological crisis) - was clearly present in all Eastern European countries both before and after the fall of communist regimes. Both groups of my respondents indicated confrontation with environmental problems as the main reason for joining them. However, given that during the democratic period the old environmental problems originating in the pre-1989 period were not resolved while new problems emerged, the decline of both the Green Party and environmental groups during the first half of the 1990s suggests that persisting ecological crisis on its own does not necessarily maintain environmental concern. It seems that this

2) While in the EU 60 per cent of the workforce worked in the tertiary sector in 1988, this figure in the Czech Republic was 40 per cent [Kopačka 1996].

3) For instance, by 1993, the share of people working in the tertiary sector in the Czech Republic had increased to 49 per cent in comparison with 40 per cent in 1988 [Kopačka 1996]. 
'shallow' environmental concern championed in the Czech Republic mainly by the Greens, which frames environmental issues primarily in terms of pollution, is not connected with value change and can be therefore easily superseded by other, more immediate problems.

Despite the fact that ecological crisis and also to a limited extent socio-economic status as factors influencing the support for environmentalism were present in the Czech Republic both prior to and after 1989, environmentalism of a Western kind has not developed. This leaves me to examine the role of the third factor influencing support for Western environmentalism - value change. Despite serious reservations about postmaterialism as a single explanatory factor of the rise of Western environmentalism, postmaterialism remains an important tool for detecting social groups prone to hold positive attitudes to and support for environmentalism. It was empirically proven that the majority of greens and activists of environmental movements in the West are post-materialists. A much lower share of post-materialists among the two Czech groups of respondents in comparison with Western environmentalists is one of the most striking findings of my surveys. This applies particularly to the extremely highly educated Nika readers as postmaterialism is associated, along with structural shifts in employment, with the expansion of higher education. Since post-materialism as a manifestation of value change is deemed to have its origin in formative processes of childhood, adolescence and adult socialisation (family, education and occupation) it is necessary to focus on differences in socialisation experiences between Western and Central European environmentalists. In general, it is argued that highly educated professionals working in service sectors are most likely to be post-materialists and consequently environmentalists.

Rootes [1994] narrows down these criteria drawing on empirical findings that in the West the membership of environmental groups and Green Parties 4 is composed predominantly of highly educated social, cultural and human service professionals. He argues that it is education in humanities, art and social sciences which is crucial in inculcating values positive to the environment. In comparison with other highly educated social groups, people with shared socialisation of this type are not only more likely to be concerned about the environment and understand the complexities of environmental problems but also adopt more radical political stances. A social science background is therefore highly important for the development of Western environmentalism whose features are not only deep understanding of complexities of ecological problems, but also emphasis on democratic participation, sensitivity to social justice and awareness of the interconnectedness of environmental and social issues.

The single most important factor which clearly distinguished readers of Nika - a group of people in many ways similar to members of Western environmental groups from their Western counterparts was their educational background. The Nika readers (and also the Czech Greens with experience of higher education) were conspicuous by the lack of education in social science, arts and humanities on the one hand, and by the dominance of an educational background in sciences and technology on the other. The Nika readers'

4) Voerman's (1995) survey of the members of the Dutch Green Left party revealed that not only more than 80 per cent of his respondents - members of the party - appeared to have attended some form of higher education, but also that among the highly educated, social scientists were best represented (42 per cent) with the arts in second place. The British Greens are also dominated by social science, arts and humanities graduates [Rüdig et al. 1991]. 
awareness of the global dimension of environmental issues is explained by their academic expertise resulting from their high education in biology and related disciplines, as well as from the fact that a significant part of them worked in academia. Academia in all Central European countries was, during the communist regime as well as in the mid-1990s, dominated by technology and science. As they were close to 'information channels', Nika respondents knew of the problems and even might have been alarmed by them. Contrasting the Nika readers with the Czech Greens is quite illustrative here. The Greens' level of education was considerably lower and therefore their perception of environmental problems did not go beyond immediate 'local' concern.

\section{Conclusion}

The first post-1989 generation of Czech environmental policy makers who were elevated to their posts due to the unique circumstances of the time pushed progressive environmental policies which were abandoned once this group of people lost power in 1992. Sociologically, the explanation of this complete change rests on a lack of social basis for the pursuit of advanced environmental policies typical of the first two years of the 1990s. The environmental policy community remained limited due to the existence in the Czech Republic of specific barriers to general social trends which gave rise to the "new politics of pollution' in Western Europe in the 1980s.

PETR JEHLIČKA is a part-time researcher in the Institute of Sociology of the Czech Academy of Sciences in Prague and a lecturer in human geography at the Department of Social Geography and Regional Development at Charles University. His principal areas of research are environmental politics and policy and political geography. He is currently a member of an international team of the research project "Czech and Slovak environmental NGOs ten years after".

\section{References}

Čech, P. 1997. "Varování z Evropy” (Warning from Europe). Nika 18, No. 3-4: 55.

Environmental Needs Assessment. Regional Report 1994. Budapest: The Regional Environmental Center for Central and Eastern Europe.

Fagin, A. 1996. "The Transition to Democracy in the Czech Republic - An Alternative Perspective and Assessment." PhD thesis, University of Manchester, Manchester.

Fagin, A., P. Jehlička 1997. "The Czech Republic: Sustainable Development - A Doomed Concept?" In Dilemmas of Transition: The Environment, Democracy and Economic Reform in East Central Europe, ed. by S. Baker, P. Jehlička. London: Frank Cass.

Hansen, A. 1993. "Introduction.” In The Mass Media and Environmental Issues, ed. by A. Hansen. Leicester: Leicester University Press.

Holy, L. 1996. The Little Czech and the Great Czech Nation. National identity and the postcommunist social transformation. Cambridge: Cambridge University Press.

Jachtenfuchs, M., M. Huber 1993. "Institutional learning in the European Community: the response to the greenhouse effect." In European Integration \& Environmental Policy, ed. by J. D. Liefferink, P. D. Lowe, A. P. J. Mol. London: Belhaven Press.

Jehlička, P., J. Kára 1994. "Ups and Downs of Czech Environmental Awareness and Policy: Identifying Trends and Influences." In Protecting the Periphery. Environmental Policy in Peripheral Regions of the European Union, ed. by S. Baker, K. Milton, S. Yearley. London: Frank Cass.

Kopačka, L. 1996. "Strukturální změny ekonomiky se zvláštním zřetelem k průmyslu" (Structural Changes of the Economy with Special Reference to Industry). In Geografická organizace 
společnosti a transformační procesy v České republice, ed. by M. Hampl. Praha: Př́rodovědecká fakulta UK.

Lacey, C., D. Longman 1993. "The press and public access to the environment and development debate." The Sociological Review 41: 207-243.

Poguntke, T. 1993. Alternative Politics. The German Green Party. Edinburgh: Edinburgh University Press.

Poláček, M. 1996. "Evropské unii vadí česká energetika" (European Union Criticises Czech Energy Sector). (Interview with Matti Wuori). Lidové noviny, 11 December.

Rootes, C. A. 1994. "A New Class? The Higher Educated and the New Politics." In Movements and Social Classes, ed. by L. Maheu. Beverly Hills: SAGE.

Rüdig, W., L. Bennie, M. Franklin 1991. Green Party members: a profile. Glasgow: Delta.

Stanners, D., P. Bourdeau 1995. Europe's Environment. The Dobris Assessment. Copenhagen: European Environment Agency.

Vavroušek, J. 1993. "Institutions for Environmental Security." In Threats without Enemies. Facing Environmental Security, ed. by G. Prins. London: Earthscan.

Weale, A. 1992. The New Politics of Pollution. Manchester: Manchester University Press. 